\title{
THE RELATIONSHIP AMONG IMMUNE RESPONSE TO SRBC ANTIGEN AND SOME ENDOGENOUS ANTIOXIDANT ENZYME ACTIVITIES IN CHICKENS
}

\author{
A. A. El-Fiky, G. M. Gebriel, F. H. Abdou and M. Kahiel \\ Dept. of poultry and Fish Production, faculty of Agric., Menoufia Univ., Egypt.
}

Received: Apr. 23, 2019

Accepted: Apr. 30,2019

\begin{abstract}
This experiment was conducted during the period from February 2017 until June 2018. The experiment was designed to study the relationship among immune response to the SRBC antigen, and some endogenous antioxidant enzymes activities in chickens.
\end{abstract}

The results can be summarized in the following points:

1- The highest activity of the catalase enzyme was achieved in the low immunity group of Norfa chickens, whereas the lowest activity of the catalase enzyme was in the high immunity one while the control group was medium between the two groups.

2- Studing the relationship between superoxide dismutase activity and immune response to antibody indicated that, the highest activity value of superoxide dismutase was recorded for the low immunity group. On the other hand, the lowest activity of (SOD) was observed in the high immunity group.

3- The relation between Malondialdehyde concentration (oxidative stress) and immunity groups indicated that, there were no significant differences between the high immunity group and the control one in MDA concentration. There were significant differences between the low immunity group and the two others.

4- The present results demonstrated that there were highly significant $(P \leq 0.01)$ negative correlation between antibody titers and both CAT and SOD antioxidant enzymes activities. While MDA concentration had highly significant positive correlation with antibody titers.

Key words: Immune response, endogenous antioxidant enzymes, Norfa chickens.

\section{INTRODUCTION}

Oxidative stress in chicken can result in damages to biomolecules, cells and tissues which thereby can decrease immunity, antioxidant system result in poor growth rate and production of the birds. Lipid peroxidation of polyunsaturated fatty acids (PUFA) results in the formation of by products like malondialdehyde which is measured in terms of TBARS (Thiobarbituric acid reactive substance). Lipid peroxidation is an index for the oxidative stress which results in higher malondialdehyde (MDA) (Keshavamurthy et al., 2013).
Endogenous antioxidant enzymes are the major cell defense against oxidative stress. Glutathione peroxidase (GSH-Px) and catalase (CAT) are considered the major peroxide-removing enzymes located in the cytosol. Superoxide dismutase (SOD) plays an important role in protecting against damage by the radical superoxide anion (Chan and Decker, 1994), indicating its importance in scavenging excessive ROS produced by the tissues.

On the other hand, an immune system is a system of biological structures and processes within an organism that protects against diseases by identifying 
and killing pathogens and tumor cells. It detects a wide varity of agents, from viruses to parasitic worms and needs to distinguish them from the organism's own healthy cells and tissues in order to avoid harmful of itself (Gebriel et al., 1979).

The immune cell functions such those involved in the cytotoxic activity and particularly in phagocytes as regards their microbicidal activity, are specially linked to reactive oxygen species (ROS) generation. However, as mentioned above, excessive amounts of ROS which are not counteracted by the antioxidant defenses of the cell, can become a source of tissue damage, since free radicals can attack cellular components and lead to death because of the molecular damage resulting from oxidative stress (Fuente, 2002).

The immune cell functions are strongly influenced by the antioxidant/oxidant balance. There fore, the antioxidant levels in these cells play a pivotal role in maintaining immune cells in a reduced environment and in protecting them from oxidative stress and preserving their adequate function (Knight, 2000). More specifically, antioxidants maintain the integrity and function of cellular membrane lipids, proteins, and nucleic acids and the control of signal transduction of gene expression in immune cells.

Lipid peroxidation is an autocatalytic free radical reaction whereby polyunsaturated fatty acids and phospholipids undergo degradation by a chain reaction that results in the formation of lipoperoxides, various aldehydes (e.g., malondialdehyde, 4hydroxynonenal), and short chain hydrocarbons (e.g., ethane, propane, pentane), among others (Knight,. 1999). As much as, lipid peroxidation damages the bi-lipid cell membrane, the result is an altered immune system, since a functioning membrane is necessary for normal membrane metabolic activity as well as antigen reception, secretion of lymphokines and antibodies, contact cell lysis, and lymphocyte transformation. Lipid peroxidation may also result in increased prostaglandin levels which are strong immunomodulators.

Also, Bavarsadi et al. (2017) studied the effects of different levels of sanguinary on antioxidant indices and immunological responses. The result showed that increases in serum gamma globulin concentration and antibody titers against sheep red blood cells. Thus improve cellular and humoral immunity then suppress the malondialdehyde concentrations.

The present study was carried out to investigate the relationship among immune response to SRBC antigen, and some endogenous antioxidant enzymes activities in Norfa chickens.

\section{MATERIALS AND METHODS}

The present study was carried out at the Department of Poultry and Fish Production, Faculty of Agriculture, Menoufia University, Shibin El-Kom. The experiment was extended from Feb. 2017 to June 2018, to investigate the relationship among immune response to SRBC antigen, and some endogenous antioxidant enzymes activities in chickens.

\section{Chickens stock:}

Norfa strain was used in the present study as a synthetic local breed of chickens. It was developed at the Poultry Research Farm, Department of Poultry and Fish Production, Faculty of Agriculture, Menoufia University, Shibin El-Kom. Abdou (1996) presented in details the formation history of Norfa breed. All birds were subjected to similar managerial and hygienic conditions. 
2

2. Experimental management:

At hatch, chicks were pedigreed according to their dams for identification, weighed and moved to brooding house. All chicks were brooded in floor brooder with wood shaving litter. The starting brooder temperature was $34{ }^{\circ} \mathrm{C}$ during the first week, then temperature was decreased gradually from $2-3{ }^{\circ} \mathrm{C}$ every week to reach $22-24^{\circ} \mathrm{C}$ at almost 42 days of age. The chicks were moved to rearing house at eight weeks of age.

All chicks were exposed to continuous artificial light for 24 hours during the first week of age, and then the artificial light was decreased gradually to reach the natural day light by about 8 weeks of age. All chickens were received only natural day light from 9 to 17 weeks of age. At 18 weeks of age, pullets were moved to individual cages in laying house, where the hens were kept until 42 weeks of age under 16 hour of light a day.

All chicks were fed ad libitum diet (containing $19.96 \%$ crude protein and $2919 \mathrm{Kcal} \mathrm{ME} / \mathrm{Kg}$ ) during brooding and rearing periods. Whereas, chickens were fed ad libitum diet (containing $18.03 \%$ crude protein and $2910 \mathrm{Kcal}$ $\mathrm{ME} / \mathrm{Kg}$ ) during production until the end of experiment.

\section{Experimental design and treatments:}

At 20 weeks of age, the primary antibody response was determined for each individual at 7 days postimmunization. Chickens were divided into three groups based on the level of primary antibody titers against SRBC antigen 7 days post-immunization.

A total number of the base data was 75 Norfa pullet and its $(\bar{x} \pm$ SD) was (5.36 $\pm 2.44)$. The base data were divided into three immunity groups (i. e. Control, High and Low groups), as follows:

1- The control group was randomly derived from the base data and its mean was (5.37 \pm 1.48). No significant difference was found between the mean of the control group and that of the base data.

2- Selected groups: a method of selection were applied to form (HG) and (LG) groups. The criteria of getting high group was $(\bar{x}+1 \mathrm{SD})$ and it was ( $\bar{x}-0.8 \mathrm{SD})$ for low group. The means were $(8.48 \pm 1.6)$ and $(3.52 \pm 1.08)$ for high and low groups, respectively. There were highly significant differences among the derived three groups.

\section{Determination of antibody response:}

The primary antibody titers to SRBCs were determined for all individuals as the following steps:

\subsection{Antigen immunization:}

The SRBC antigen was immunized according to the method of Siegel and Gross (1980). At 20 weeks of age, the primary antibody response was determined for each individual at 7 days post immunization.

4.2. Blood samples collection and serum preparation:

Chickens were bled from the wing vein at 7 days post immunization. Before drawing blood samples, the syringes were washed with a heparin solution to prevent clotting. About 2-3 ml of blood was taken from each chicken. Serum was collected, placed in disposable tubes and frozen for subsequent laboratory analysis.

4.3. Titration and calculation of antibody titers:

The antibody in the chickens blood sera were determined by the microtiter 
method of hemagglutinin test assay described by Siegel and Gross (1980). Serum samples were titrated individually in 96- well (eight rows by 12 columns, round (U) bottom) assay plates. Antibody titers were expressed as the $\log _{2}$ of the reciprocal of the last serum dilution, in which there was positive complete hemagglutination

\section{Antioxidant enzymes preparation:}

5.1. Superoxide dismutase (SOD) enzyme activity:

Superoxide dismutase (SOD) is one of the most important enzymes in defending oxidative stress. SOD catalyses the dismutation of superoxide anion $\left(\mathrm{O}_{2}\right)$ into hydrogen peroxide and molecular oxygen $\left(\mathrm{O}_{2}\right)$. Oxidative stress through reactive oxygen species (ROS) plays an important role in the etiology and progression in certain diseases. The superoxide dismutase (SOD) was assayed in liver tissues according to the method of (Nishikimi et al., 1972). Commercial reagents kit (BioDiagnostic, CAT. No. SD-2521) was used for the analysis of superoxide dismutase.

\subsection{Catalase (CAT) enzyme activity:}

At sexual maturity (24-wk), the activity of catalase in blood serum was determined using Bio Diagnostic ${ }^{\circledR}$ reagents kit (CAT. No. CA- 2517). The analysis technique is based on the methods described by Aebi (1984). This enzyme serves as one of the body's defence systems against $\mathrm{H}_{2} \mathrm{O}_{2}$, a strong oxidant that can cause intracellular damage. Catalase reacts with a known quantity of $\mathrm{H}_{2} \mathrm{O}_{2}$; the reaction is stopped after exactly one minute with catalase inhibitor.

\subsection{Lipid peroxides}

(Malondialdehyde concentration):

Lipid peroxidation is the degradation of lipids that occurs as a result of oxidative damage and is a useful marker for oxidative stress. In this kit (BioDiagnostic, CAT. No. MD-2529), lipid peroxidation is determined by the reaction of MDA with Thiobarbituric acid (TBA) to form a colorimetric (525 nm) product, proportional to the malondialdehyde (MDA) present. This assay was used by Nair and Turner (1984).

\section{Studied traits:}

The following traits were studied during the experimental period:

6.1. Determination of primary antibody titers to SRBC antigen, which determined at 20wk of age in chickens.

6.2. Determination of antioxidant enzymes activities in control and selected immunity groups of chickens at sexual maturity (24wk), which included catalase enzyme (CAT), superoxide dismutase enzyme (SOD) and malondialdehyde (MDA).

\section{Statistical analysis:}

Least square means and their standard errors $(X \pm S E)$ for each studied trait were calculated for each group. Data obtained were statistically analyzed using SPSS (2004). Probability value, ( $P \leq$ 0.05 ) was considered for significant. All percentages data were converted to the corresponding arcsine prior statistical analysis as given by SAS (1988). Duncan's multiple range test was used for the multiple comparisons of means (Duncan, 1955).

One way classification statistical fixed model was used for statistical analysis as the following:

Where:

$$
Y_{i j}=\mu+G_{i}+e_{i j}
$$

$Y_{i j}=$ The $I^{\text {th }}$ observation of the individual over all means.

$\mu=$ The common mean.

$G_{i}=$ The fixed effect of antibody response. 
$\mathbf{e}_{\mathrm{ij}}=$ Experimental error .

In addition, sample correlation coefficients among antibody titer concentrations in hens, blood serum and some productive traits were calculated using the following equation as given by Snedecor and Cochran (1986):

$$
r X_{1} X_{2}=\frac{\Sigma X_{1} X_{2}}{\sqrt{\left[\Sigma X_{1}^{2}-\frac{\left(\Sigma X_{1}\right)^{2}}{n}\right]} \sqrt{\left[\Sigma X_{2}^{2}-\frac{\left(\Sigma X_{2}\right)^{2}}{n}\right]}}
$$

\section{RESULTS AND DISCUSSION}

\section{Antibody titer concentrations in} control and selected groups of Norfa chickens:

The obtained results in Table (1) showed the concentrations of antibody titer in control and selected groups of Norfa chickens. The statistical analysis of the data revealed that there were highly significant differences $(P \leq 0.01)$ in the values of antibody titer between control group and other two high and low Norfa chicken groups. The highest mean value was recorded at high Norfa group (8.48), followed by control group (5.37), while low Norfa group registered the least value (3.52).
Results also indicated that the antibody titer concentration at the high group was increased by $157.9 \%$ compared to control group (100\%), while it was only $65.5 \%$ at the low group. These results were in agreement with these cleared by Abou-Elewa (2004). She reported that highly significant differences $(P \leq 0.01)$ between lines in antibody titers were observed in Norfa strain and found that the antibody titers of the high antibody line were increased while the low one were decreased. The percentages of change of antibody titer from the control line (100.0\%) were 115.1 and $88.9 \%$ for high and low lines, respectively in Norfa chickens.

The superiority of high group over control and low group in the present study is consistent with the results of Siegel and Gross (1980), Ubosi et al. (1985), Martin et al. (1990), Pinard et al. (1992) and Yang et al. (2000), who measured the antibody response to SRBC, in lines of chickens divergently selected for high and low antibody titers. They found that there were statistical differences between lines and the chickens of the high line had significantly higher antibody titer than those from the low and control lines.

Table (1): Antibody titer concentrations $(\bar{x} \pm S E)$ in control and selected groups of Norfa chickens.

\begin{tabular}{|c|c|c|c|}
\hline $\begin{array}{c}\text { Immunity } \\
\text { Levels }\end{array}$ & $\begin{array}{c}\text { no. of } \\
\text { chickens }\end{array}$ & $\begin{array}{c}\text { Antibody titer concentrations } \\
(\bar{X} \pm \text { SE) } * *\end{array}$ & $\begin{array}{c}\text { \% change of } \\
\text { control }\end{array}$ \\
\hline Control( CG) & 21 & $5.37 \pm 0.325^{\mathrm{b}}$ & 100 \\
\hline High( HG) & 20 & $8.48 \pm 0.360^{\mathrm{a}}$ & 157.9 \\
\hline Low( LG) & 34 & $3.52 \pm 0.187^{\mathrm{c}}$ & 65.5 \\
\hline
\end{tabular}

a, b, c, :Means in the same column bearing different superscripts are significantly different . $* *=$ Highly significant $(P \leq 0.01)$. 


\section{Effect of antibody titer concentrations on endogenous antioxidant enzymes in control and selected groups of Norfa chickens:}

\subsection{Catalase enzyme (CAT):}

Activity of catalase enzyme of Norfa chicken groups as affected by antibody titer concentrations are presented in Table (2) and Figure (1). The statistical analysis of the obtained data revealed that the low immunity group of Norfa chickens was recorded the highest significant value of catalase enzyme $(647.490 \pm 29.613)$ when compared with control group $(399.218 \pm 6.439)$, while high immunity group recorded the lowest concentrations (321.539 \pm 12.183$)$ of catalase activity.

Results also indicated that catalase enzyme at the low immunity group was increased by $162.18 \%$ compared to control one $(100 \%)$, while it was $80.54 \%$ in the high immunity group.

The obtained results are in harmony with Keshavamurthy et al. (2013) who reported a significant increase in catalase activity and a significant decrease in the lipid peroxidation levels by decreasing the formation of malondialdehyde in the liver tissues in comparison to the control. In addition, Yardibi and Türkay (2008) found significant increases in plasma malondialdehyde (MDA), catalase (CAT), superoxide dismutase (SOD). Furthermore, Abdel Azim and Farahat (2009) found significant differences in GPX, CAT and SOD antioxidant enzymes activities among different chicken breeds.

\subsection{Superoxide dismutase enzyme (SOD):}

Superoxide dismutase enzyme activity of Norfa chicken groups as affected by antibody titer concentrations presented in Table (3) and Fig. (2). The statistical analysis of the obtained data revealed that the low immunity group of Norfa chickens was recorded the highest significant value of superoxide dismutase enzyme (636.358 \pm 6.565) when compared with control group $(544.750 \pm 5.320)$. Whereas high group recorded the lowest activity (355.193 \pm 32.311) of SOD.

Results also indicated that superoxide dismutase enzyme under the low immunity group of Norfa chicken was increased by $116.81 \%$ compared to control one $(100 \%)$, while it was $65.20 \%$ at the high group.

The obtained results are in harmony with Abd El-Hack and Alagawany (2015) who found a significantly positive effect on parameters related to immunity and lipid profile, in addition to serum superoxide dismutase activity. Also, Ahmed et al. (2017) found an improvement in the performance and immunity in Bandarah chickens and this lead to increase of superoxide dismutase (SOD) and decrement of plasma lipid peroxidation based on MDA was significantly in treated groups.

\subsection{Malondialdehyde concentration:}

(MDA)

The obtained results in the Table (4) and Fig. (3) showed the level of lipid peroxidation, as indicated by malondialdehyde (MDA) formation ( $n$ $\mathrm{mol} / \mathrm{ml}$ ) of the three different immunity groups of chickens.The statistical analysis of the obtained data revealed that no significant difference was recorded in the malondialdehyde values between the high immunity group of Norfa chickens and control one, (11.630, $10.574 \mathrm{n} \mathrm{mol} / \mathrm{ml}$ ) . It was only $5.472 \mathrm{n}$ 
$\mathrm{mol} / \mathrm{ml}$ in (LG) which recording control groups. significant differences with both high and Table (2): Effect of antibody titer levels on catalase activity (U/L) $(\bar{X} \pm S E)$ in Norfa chickens.

\begin{tabular}{|c|c|c|c|}
\hline $\begin{array}{c}\text { Immunity } \\
\text { Levels }\end{array}$ & $\begin{array}{c}\text { no. of } \\
\text { chickens }\end{array}$ & $\begin{array}{c}\text { Catalase (U/L) } \\
(\bar{X} \pm \mathrm{SE})^{* *}\end{array}$ & $\begin{array}{c}\text { \% change of } \\
\text { control }\end{array}$ \\
\hline Control( CG) & 12 & $399.218 \pm 6.439^{\mathrm{b}}$ & 100 \\
\hline High( HG) & 14 & $321.539 \pm 12.183^{\mathrm{c}}$ & 80.54 \\
\hline Low( LG) & 24 & $647.490 \pm 29.613^{\mathrm{a}}$ & 162.18 \\
\hline
\end{tabular}

a, b, c, :Means in the same column bearing different superscripts are significantly different . $* *=$ Highly significant $(P \leq 0.01)$.

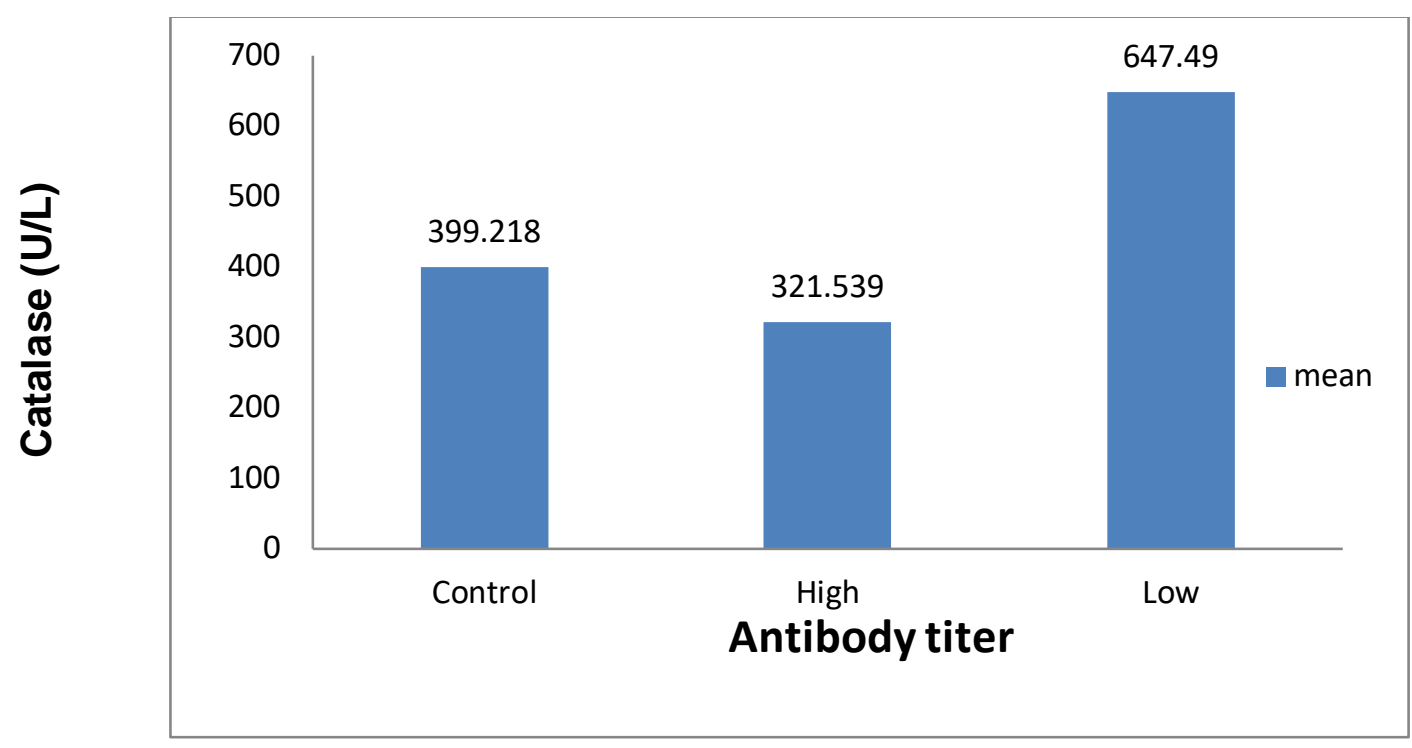

Fig. (1): Effect of antibody titers concentrations on catalase enzyme activity in Norfa chickens.

Table (3): Effect of antibody titer levels on superoxide dismutase activity ( $\bar{x} \pm \mathrm{SE})$ in Norfa chickens.

\begin{tabular}{|c|c|c|c|}
\hline $\begin{array}{c}\text { Immunity } \\
\text { Levels }\end{array}$ & $\begin{array}{c}\text { no. of } \\
\text { chickens }\end{array}$ & $\begin{array}{c}\text { superoxide dismutase activity(U/L) } \\
(\bar{X} \pm S E)^{* *}\end{array}$ & $\begin{array}{c}\% \text { change of } \\
\text { control }\end{array}$ \\
\hline Control( CG) & 12 & $544.750 \pm 5.320^{\mathrm{b}}$ & 100 \\
\hline High( HG) & 14 & $355.193 \pm 32.311^{\mathrm{c}}$ & 65.20 \\
\hline
\end{tabular}


A. A. El-Fiky, et al.,

\begin{tabular}{|c|c|c|c|}
\hline $\operatorname{Low}($ LG) & 24 & $636.358 \pm 6.565^{\mathrm{a}}$ & 116.81 \\
\hline
\end{tabular}

a, b, c, :Means in the same column bearing different superscripts are significantly different . $* *=$ Highly significant $(P \leq 0.01)$.

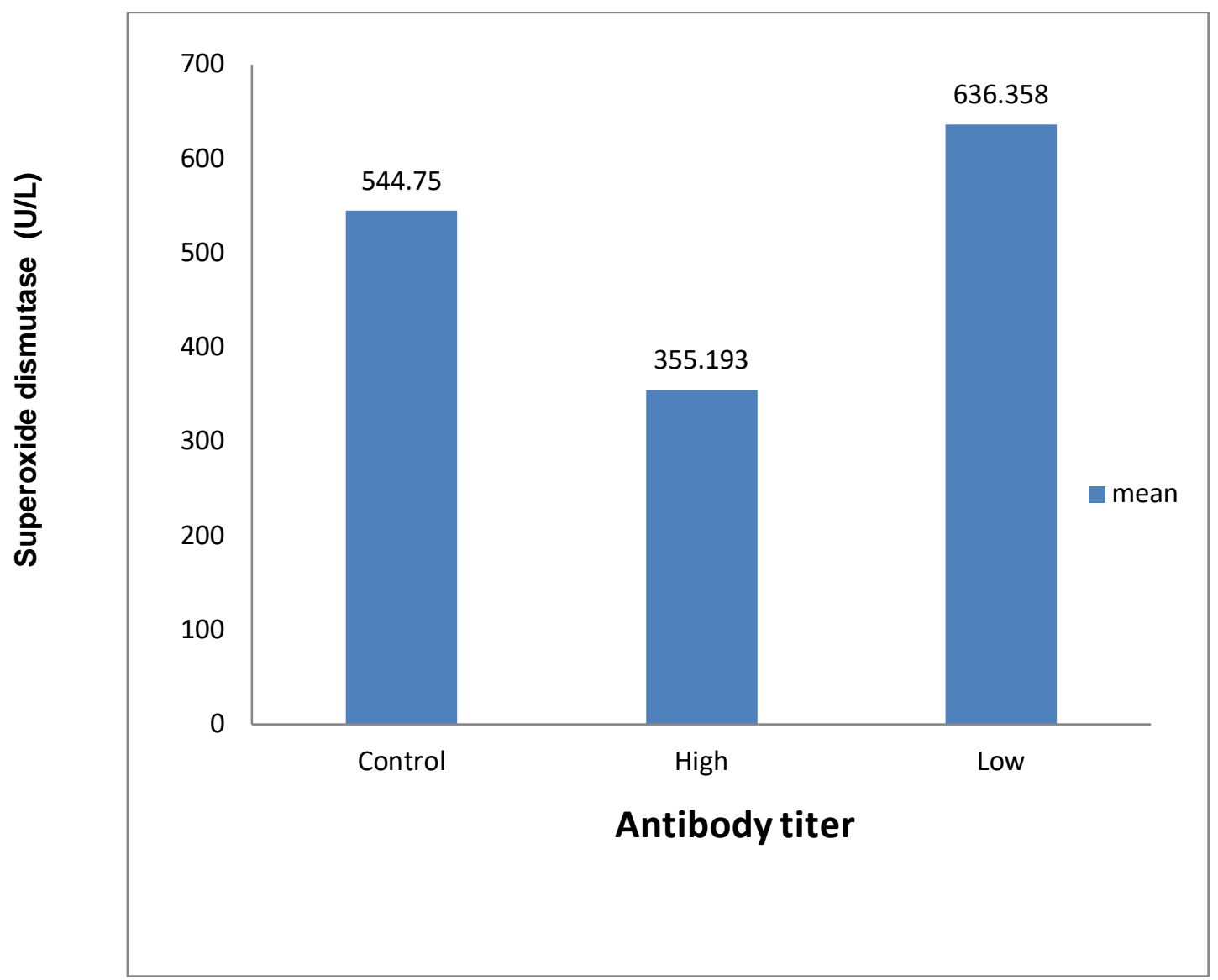

Fig. (2): Effect of antibody titers on concentration of superoxide dismutase enzyme in Norfa chickens.

Table (4): Effect of antibody titer levels on malondialdehyde concentration $(\bar{X} \pm \mathrm{SE})$ in Norfa chickens.

\begin{tabular}{|c|c|c|c|}
\hline $\begin{array}{c}\text { Immunity } \\
\text { Levels }\end{array}$ & $\begin{array}{c}\text { no. of } \\
\text { chickens }\end{array}$ & $\begin{array}{c}\text { Malondialdehyde(n mol/ml) } \\
(\bar{X} \pm \text { SE) })^{* *}\end{array}$ & $\begin{array}{c}\text { \% change of } \\
\text { control }\end{array}$ \\
\hline Control ( CG) & 12 & $10.574 \pm 0.351^{\mathrm{a}}$ & 100 \\
\hline High ( HG) & 14 & $11.63 \pm 0.36^{\mathrm{a}}$ & 109.9 \\
\hline
\end{tabular}




\begin{tabular}{|c|c|c|c|}
\hline Low (LG) & 24 & $5.472 \pm 0.55^{\mathrm{b}}$ & 51.7 \\
\hline
\end{tabular}

a, b, c, :Means in the same column bearing different superscripts are significantly different .

$* *=$ Highly significant $(P \leq 0.01)$.

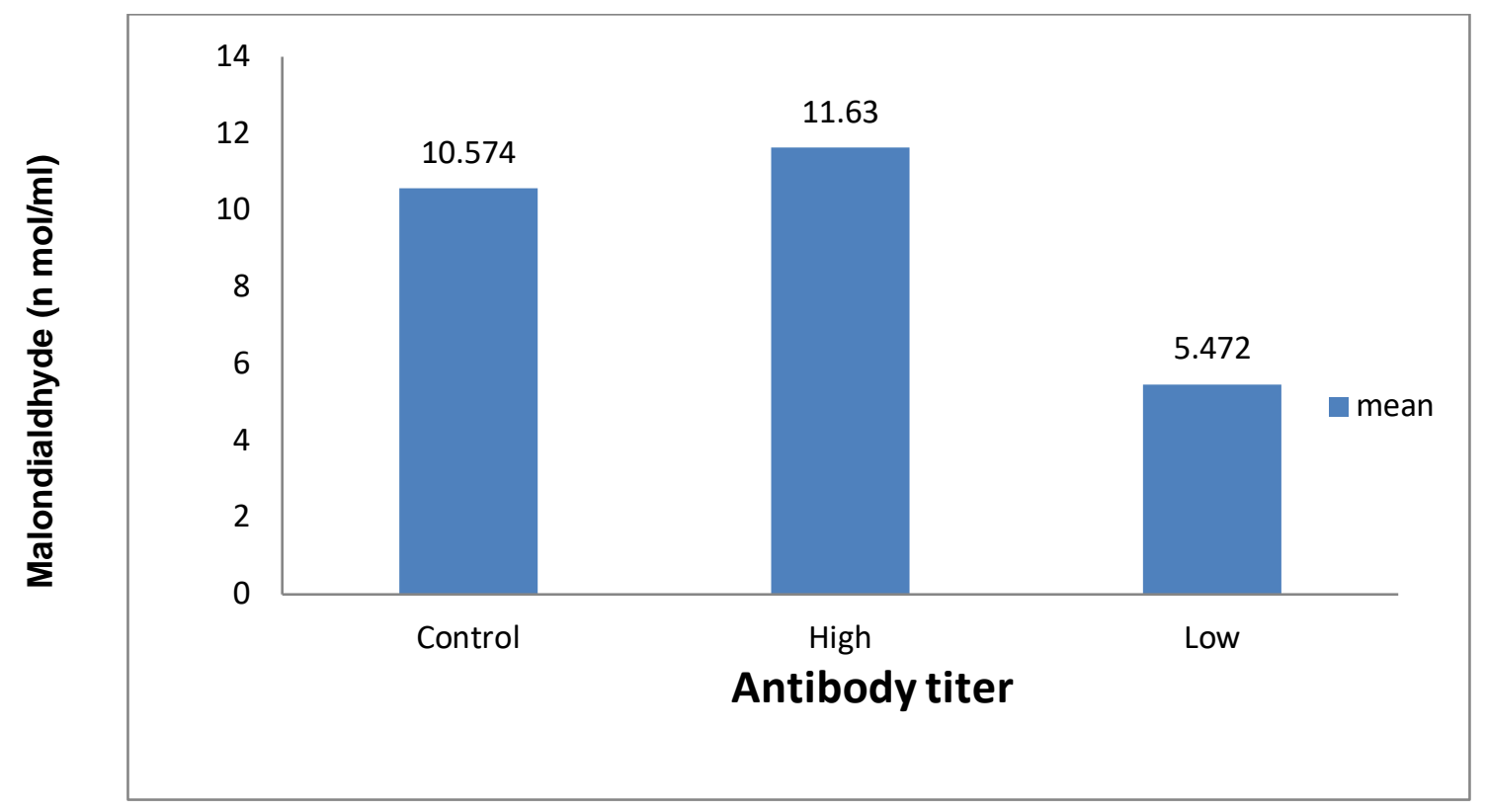

Fig. (3): Effect of antibody titers on concentrations of malondialdehyde in Norfa chickens.

The obtained results are in agreement with Knight (1999) who reported that lipid peroxidation is an autocatalytic free radical reaction whereby polyunsaturated fatty acids and phospholipids undergo degradation by a chain reaction that results in the formation of lipoperoxides, various aldehydes (e.g., malondialdehyde, 4-hydroxynonenal), and short chain hydrocarbons (e.g., ethane, propane, pentane).

Also, Hashemipour et al. (2013) registered a significant increased $(P \leq$ 0.05 ) in superoxide dismutase and glutathione peroxidase activities and significant decrease $(P \leq 0.05)$ in malondialdehyde level in thigh muscle at d 42 and serum and liver at 24 and 42 days. They observed an improved immune response of broilers by increasing hypersensitivity response, total and IgG anti-sheep red blood cell titers, and decreasing heterophil to lymphocyte ratio compared with the control group.

In addition, Bavarsadi et al. (2017) recorded increases in serum antibody titers against sheep red blood cells, which improved cellular and humoral immunity, then decrease the malondialdehyde concentrations.

\subsection{Correlation coefficients among antibody titer, catalase, superoxide dismutase enzyme activities and malondialdehyde concentration in Norfa chickens: \\ The sample correlations among antibody titer and each of catalase (CAT), superoxide dismutase (SOD) enzymes and malondialdehyde (MDA) in Norfa}


chicken recorded in (Table 5) and illustrated in Fig. (4). The results indicated that, there were negative highly significant correlation coefficients between antibody titer and catalase. Also between antibody titer and superoxide dismutase, while there was strong positive highly significant sample correlation coefficients between antibody titer and malondialdehyde, in Norfa chickens.

The present results concluded that there were highly significant $(P \leq 0.01)$ negative correlations between antibody titers and both CAT and SOD antioxidant enzymes activities. Whereas MDA had highly significant positive correction with antibody titers.

The immune cell functions such as those involved in the cytotoxic activity and particularly in phagocytes as regards their microbicidal activity, are specially linked to reactive oxygen species (ROS) generation. However, as mentioned above, excessive amounts of ROS which are not counteracted by the antioxidant defenses of the cell, can become a source of tissue damage, since free radicals can attack cellular components and lead to death because of the molecular damage resulting from oxidative stress (Fuente, 2002).

Thus, the immune cell functions are strongly influenced by the antioxidant/oxidant balance and, therefore, the antioxidant levels in these cells play a pivotal role in maintaining Table (5): Correlation coefficients among antibody titer, catalase (CAT), superoxide dismutase (SOD) and malondialdehyde (MDA) in Norfa chickens.

\begin{tabular}{|c|c|c|c|c|}
\hline & Antibody titer & CAT & SOD & MDA \\
\hline $\begin{array}{c}\text { Antibody } \\
\text { titer }\end{array}$ & 1 & $-0.799^{* *}$ & $-0.860^{* *}$ & $0.775^{* *}$ \\
\hline CAT & $-0.799^{* *}$ & 1 & $0.801^{* *}$ & $-0.582^{* *}$ \\
\hline
\end{tabular}

immune cells in a reduced environment and in protecting them from oxidative stress and preserving their adequate function (Knight, 2000).

More specifically, antioxidants maintain the integrity and function of membrane lipids, cellular proteins, and nucleic acids and the control of signal transduction of gene expression in immune cells. For this reason the immune cells are particularly sensitive to changes in their antioxidant status. Moreover, since the immune system cells have a high percentage of polyunsatured fatty acids in their plasma membrane, it is not surprising that these cells usually contain higher concentrations of antioxidants than do other cells (Knight, 2000). Indeed, since the early years of the twentieth century the history of the relationship between antioxidants and immunology began with an appreciation that antioxidant nutrient deficiencies may cause disease, and that antioxidants have an immunostimulating action. Although recent results throw doubt on this concept, since a total neutralization of ROS could block their functional role and higher levels of antioxidants can produce oxidant effects, the administration of antioxidants has been shown to improve several immune functions. 
The relationship among immune response to srbc antigen and some

\begin{tabular}{|c|c|c|c|c|}
\hline SOD & $-0.860^{* *}$ & $0.801^{* *}$ & 1 & $-0.542^{* *}$ \\
\hline MDA & $0.775^{* *}$ & $-0.582^{* *}$ & $-0.542^{* *}$ & 1 \\
\hline
\end{tabular}

${ }^{* *}$ Highly significant correlations $(P \leq 0.01)$.
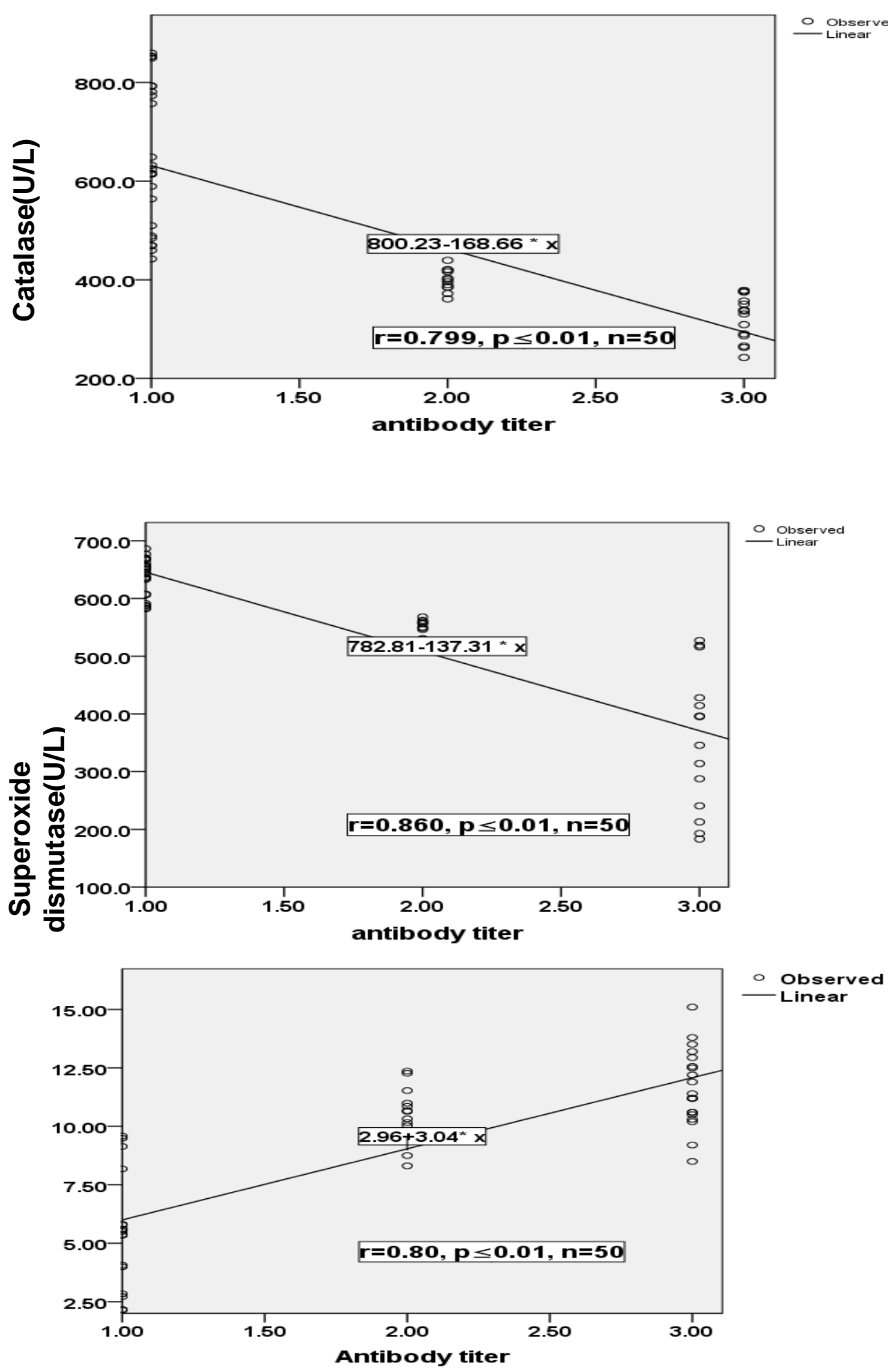
Fig. (4): Correlation coefficients among antibody titer and each of catalase, superoxide dismutase and malondialdehyde in Norfa chickens.

It was reported that the most natural antioxidants were namely ascorbic acid (vitamin $C$ in humans and guinea pigs, which is an important cytoplasmic antioxidant), vitamin E (which is considered the principal antioxidant defense against lipid peroxidation in the cell membrane of mammals), glutathione (GSH, which is the most abundant nonprotein thiol-containing substance in living organisms and, in its reduced form, is one of the key links in the chain of antioxidant defenses protecting molecules against ROS damage) or other compounds which raise the tissue levels of thiol groups, such as thioproline (which is anti-toxic in the liver and increases life span in mice) or Nacetylcysteine (NAC, which shows a wide range of effects at all cellular levels such as inhibitory action on apoptosis, proinflammatory cytokine production, carcinogenic action of some compounds and metastasis), seem to be excellent controller of injurious oxidation. Moreover, the levels of these antioxidants decrease during oxidative stress (Fuente, 2002).

All these antioxidants have been shown to improve the immune functions in vitro and in vivo (Correa et al., 1999;
Fuente and Victor, 2000 and Victor and Fuente, 2002). Furthermore, they inhibit the activation of the nuclear transcription factor NF-kB produced by oxidative stress, which could result in a decrease of free radicals and pro-inflammatory cytokine production. Therefore, the above-mentioned antioxidants also have an anti-inflammatory action.

\section{REFERENCES}

Abd El-Hack, M. E. and M. Alagawany (2015). Performance, egg quality, blood profile, immune function, and antioxidant enzyme activities in laying hens fed diets with thyme powder. Journal of Animal and Feed Sciences, 24: 127-133.

Abdel Azim, A. M. and Gihan S. Farahat (2009): Breed differences and phenotypic correlations of antioxidant enzymes activities, some physiological parameters and productive traits of chicken 2 . Phenotypic correlations. Egyptian Poultry Science Journal. 29 (II): 645666.

Abdou, F. H. (1996). Improving endogenous chickens breeds: Experience from Egypt, Norway and 
Tanzania. Egyptian Journal Animal Production ., 33, Suppl. 567 - 576.

Abou-Elewa, Eman M. (2004). Selection for general immune response and its relation to some economic traits in chickens. M.Sc. Thesis, Faculty of Agric., (Poultry Production), Minoufiya University.

Aebi, H. (1984). Methods Enzymol. 105: 121 - 126.

Ahmed, M. M.; A. S. El-Saadany; E. Y. Shreif and A. M. El-Barbary (2017): Effect of dietary olive leaves extract (Oleuropein) supplementation on productive, physiological and immunological parameters in Bandarah chickens. 2 - During production period. Egyptian Poultry Science Journal; 37 (1): 277 - 292.

Bavarsadi, M., A. H. Mahdavi, S. AnsariMahyari and E. Jahanian (2017). Effects of different levels of sanguinarine on antioxidant indices, immunological responses, ileal microbial counts and jejunal morphology of laying hens fed diets with different levels of crude protein. Animal physiology and animal nutrition.101 (5): 936 - 948.

Chan, K. and E. Decker (1994). Endogenous skeletal muscle antioxidants. Critical Reviews in Food Science and nutrition. 34 : $403-426$.

Correa, R., B. Blanco, M. Del Rı'o, V. Victor, N. Guayerbas, S. Medina and M. De la Fuente (1999). Effect of a diet supplemented with thioproline on murine macrophage function in a model of premature ageing. Biofactors 10, $195-200$.

Duncan, D.B. (1955). Multiple range and multiple f. Test Biometrics, 11:1.

Fuente, M. (2002). Effects of antioxidants on immune system ageing. European
Journal of Clinical Nutrition 56, Suppl (3), S5-S8. Nature Publishing Group.

Fuente, M. De la and V.M. Victor (2000). Antioxidants as modulators of immune function. Immunol. Cell Biol. 78: 49 - 54.

Gebriel, G.M., I.Y. Pevzner and A.W. Nordskog (1979). Linkage between immune response to GAT and the fate of RSV-Induce tumours in chickens. Immuno genetics, 9: 327.

Hashemipour, H., H. Kermanshahi, A. Golian and T. Veldkamp (2013). Effect of thymol and carvacrol feed supplementation on performance, antioxidant enzyme activities, fatty acid composition, digestive enzyme activities, and immune response in broiler chickens. Poultry Science., 92 :2059 - 2069.

Keshavamurthy, S.R., Shiva Kumar, C.B. Manohar and K.C. Sharadamma (2013). Effect of antioxidant formulation supplementation through water on antioxidant status of broiler chicken. International Journal of Advanced Biological Research. 3(3) 2013: 470 - 474.

Knight, J.A. (1999). Free radicals: their presence in biological systems. In free radicals, antioxidants, aging, and disease. Amerassnclinchem press, washington, DC, 1-31.

Knight, J.A. (2000). Review: free radicals, antioxidants and immune system. Annual Clinical Laboratory. Science. 30, 145 - 158.

Martin, A., E.A. Dunning, W.B. Gross and B. Seigel (1990). Production trait and alloantigen systems in lines of chickens selected for high and low antibody responses to sheep erythrocytes. Poultry Sci., 69: 871 878. 
Nair Vasu and Gregory A. Turner (1984). The thiobarbituric acid test for lipid peroxidation structure of the adduct with malondialdehyde. American Oil Chemists Society. 19, $10: 804$ - 805

Nishikimi, M., N.A. Roa and K. Yogi (1972). The Occurrence of Supeoxide Anion in the Reaction of Reduced Phenazine Methosulfate and Molecular Oxygen. Biochemical Biophysical Research Communications. 46: 849 - 854.

Pinard, M. H., J. A. M. Van Arendonk, M. G. B. Neuwland and A. J. Van der Zijpp (1992). Divergent selection for immune responsivenessin chickens: estimation of realized heritability with an animal model. Journal of Animal Science., 70: 2986 - 2993.

SAS (1988). As the foundation for SAS analytics SASISTAT provides state of the art statical analysis software that empowers you to make new discoveries. Science. 89: 259 - 279.

Siegel, P.B. and W.B. Gross (1980). Production and persistence of antibody response to sheep erythocytes. 1. Directional selection poultry Sci., 59 1-6.

Snedecor, G. and W.G. Cochran (1986). Statistical Methods, Sixth Edition,
Eighth Printing. lowa State University Press, Ames, lowa, U.S.A.

SPSS, (2004). PC. Programe by spss inc., North Michigan, US.A.

Ubosi, C. O., E. A. Dunnington, W. B. Gross and P. B. Siegel (1985). Divergent selection of chickens for antibody response to sheep erythrocytes kintics of primary and secondary immunizations. Avian Diseases. 29: 347 - 355.

Victor, V. M. and M. De la Fuente (2002). $\mathrm{N}$-acetylcysteine improves in vitro the function of macrophages from mice with endotoxininduced oxidative stress. Free Radicals. Resersh. 36, 33 $-45$.

Yang, N.C., T. Larsen, E.A. Dunnington, P.A. Geraert, M. Picard and P.B. Siegel (2000). Immune competence of chicks from two lines divergently selected for antibody response to sheep red blood cells as affected by supplemental vitamin E. Poultry Science., 79 : 799 803.

Yardibi Hasret and Gülhan Türkay (2008). The effects of vitamin $E$ on the antioxidant system, egg production, and egg quality in heat stressed laying hens. Turk. Journal Veterinary Animal Science. 32(5): 319 - 325. 
العلاقة بين الإستجابة للمناعة لكرات الام الحمراء للأغنام ونشاط الإنزيمات الداخلية

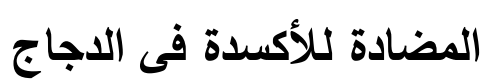

عبد المنعم عبد الحليم الفقى ، جوده محمد جبريل ، فاروق حسن عبده ، محمد كحيل

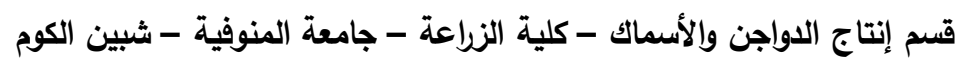

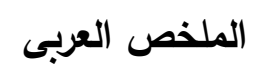

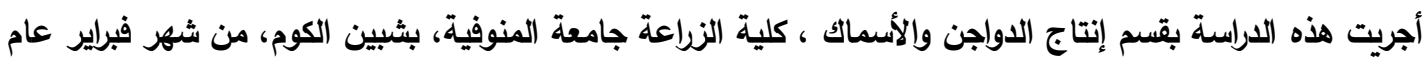

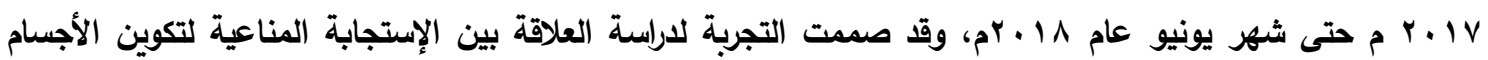

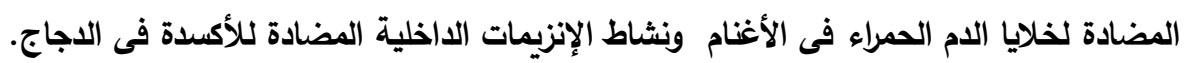

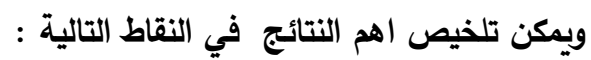

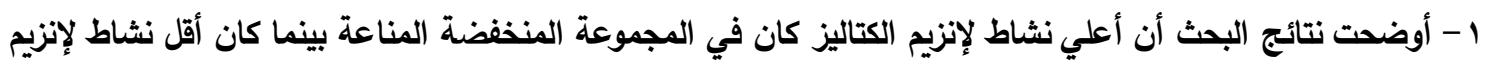

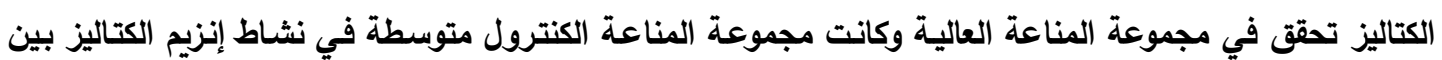
المجموعتين العالية والمنخفضة. r - وجد أن أعلي نشاط لإنزيم السوبر أكسيد ديسميوتيز تحقق في مجموعة المناعة المنخفضة بينما كان أقل نشاط لهانا الإنزيم واضحا في مجموعة المناعة العالية.

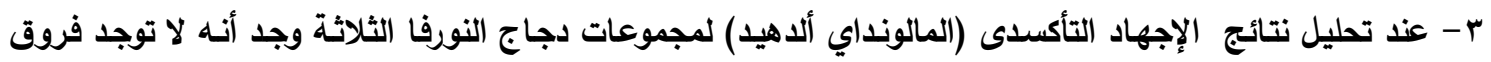

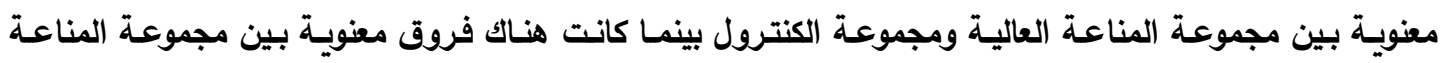

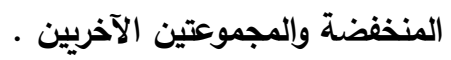

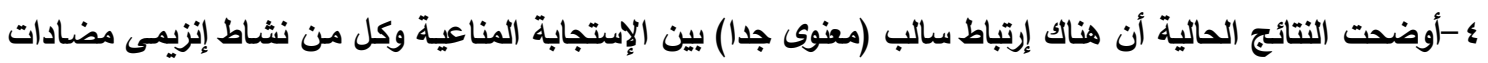

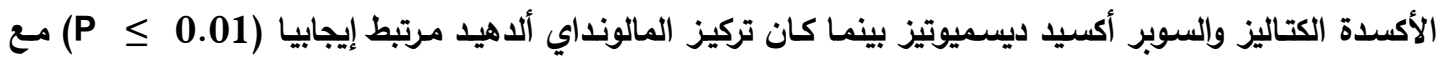

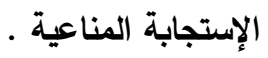


A. A. El-Fiky, et al., 